\title{
The Impacts of Higher Learning Institution on Local Industry Developments: Some Insights of Field Research in Melaka, Malaysia
}

Yew Phong Soo, Fazlinda Hamzah, Nurul Fatinah Dellah, Sumayyah Shaidin, Aida Nur Mohd Kodri

To Link this Article: http://dx.doi.org/10.6007/IJARBSS/v11-i4/8956

DOI:10.6007/IJARBSS/v11-i4/8956

Received: 14 February 2021, Revised: 17 March 2021, Accepted: 03 April 2021

Published Online: 23 April 2021

In-Text Citation: (Soo et al., 2021)

To Cite this Article: Soo, Y. P., Hamzah, F., Dellah, N. F., Shaidin, S., \& Kodri, A. N. M. (2021). The Impacts of Higher Learning Institution on Local Industry Developments: Some Insights of Field Research in Melaka, Malaysia. International Journal of Academic Research in Business and Social Sciences, 11(4), 575-584.

\section{Copyright: @ 2021 The Author(s)}

Published by Human Resource Management Academic Research Society (www.hrmars.com)

This article is published under the Creative Commons Attribution (CC BY 4.0) license. Anyone may reproduce, distribute, translate and create derivative works of this article (for both commercial and non-commercial purposes), subject to full attribution to the original publication and authors. The full terms of this license may be seen at: http://creativecommons.org/licences/by/4.0/legalcode

Vol. 11, No. 4, 2021, Pg. 575 - 584 


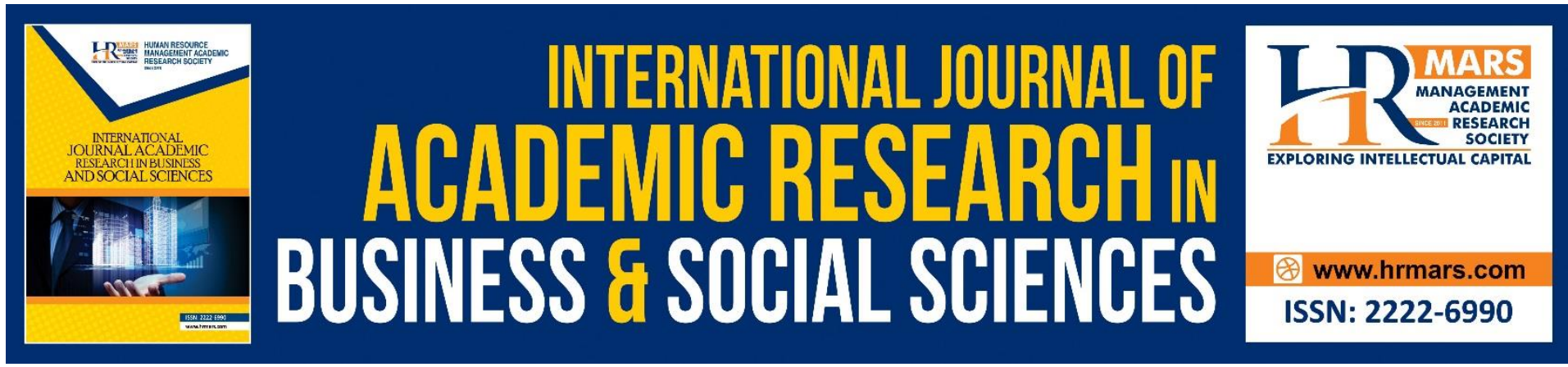

\title{
The Impacts of Higher Learning Institution on Local Industry Developments: Some Insights of Field Research in Melaka, Malaysia
}

\section{Yew Phong Soo ${ }^{1}$, Fazlinda Hamzah², Nurul Fatinah Dellah³ Sumayyah Shaidin ${ }^{4}$, Aida Nur Mohd Kodri ${ }^{5}$}

${ }^{1,2,3,4}$ Academy of Language Studies, Universiti Teknologi MARA Cawangan Melaka, Kampus Jasin, 77300 Merlimau, Melaka, Malaysia. ${ }^{5}$ Faculty of Management and Business, Universiti Teknologi MARA Cawangan Melaka, Kampus Bandaraya Melaka, 110 Off Jalan Hang Tuah,

75350 Melaka, Malaysia.

Email: sooyewphong@uitm.edu.my

\begin{abstract}
This paper seeks to identify and examine the influences of Universiti Teknologi MARA, Melaka state campus (UiTM Melaka) to the local industry development. This is based on the premise that higher learning institutions are often expected to contribute positively to the local industry where they settled in. A simple random sampling was employed, and 50 respondents participated by answering questionnaires which were prepared as a data collection method. The goal is to discover the impacts of UiTM Melaka on the local industry development, mainly in the aspects of market opportunity, consultancy, human resource, and training. Descriptive statistics and frequency analysis were utilised in the study and the results reveal that the presence of UiTM Melaka does offer significant influences on the local industry development in the stated aspects. UiTM Melaka has been found to impact mostly small local industries. Market opportunity, consultation, followed by training, and lastly human resources are four important aspects which have been impacted by the existence of UiTM Melaka. These findings provide substantial repercussions to university management and policymakers to assess existing strategies to enhance the function of universities as institutes which offer allencompassing and comprehensive relationship with the local industry or business.
\end{abstract}

Keywords: Impacts, Local Industry Development, Growth Pole Theory, Higher Learning Institution, UiTM Melaka

\section{Introduction}

The existence of universities in an area not only provides a place for the community to get educational opportunities but it is actually capable of generating economic growth in the local area. Its existence has invigorated the local industries of the surrounding area especially in retail, transportation, market opportunity, local income, traffic, and healthcare services. Furthermore, the local industries also receive consultation and training that have been provided by the universities. The presence of UiTM Melaka in Alor Gajah, Bandaraya and Jasin 
has created numerous prospects for the developments of local industries. Since its establishment, land utilization around these regions has significantly expanded particularly in Alor Gajah and Jasin. Table 1 depicts the statistics of the developed area which is perpetually rising within ten kilometres radius from UiTM Alor Gajah and Jasin in 20 years.

Table 1. Developed area from year 1999 to 2019 (10km)

\begin{tabular}{|c|c|c|c|c|}
\hline \multirow{2}{*}{$\begin{array}{c}\text { Area of UiTM } \\
\text { (ha) }\end{array}$} & \multicolumn{2}{|c|}{1999} & \multicolumn{2}{c|}{2019} \\
\cline { 2 - 5 } & $\begin{array}{c}\text { Developed } \\
\text { Area } \\
\text { (ha) }\end{array}$ & $\begin{array}{c}\text { Contribution } \\
\text { per hectare } \\
\text { (ratio) }\end{array}$ & $\begin{array}{c}\text { Developed } \\
\text { Area } \\
\text { (ha) }\end{array}$ & $\begin{array}{c}\text { Contribution } \\
\text { per hectare } \\
\text { (ratio) }\end{array}$ \\
\hline UiTM Alor Gajah & 641.97 & $4: 12$ & 7958.07 & $51: 11$ \\
155.69 & $1.34 \%$ & & $16.69 \%$ & \\
\hline UiTM Jasin & 231.84 & $2: 01$ & 4982.09 & $43: 27$ \\
$\mathbf{1 1 5 . 1 5}$ & $0.49 \%$ & & $10.43 \%$ & \\
\hline
\end{tabular}

(Source: Land Use Land Cover Report UiTM Melaka 2020)

Developed area around ten kilometres from UiTM Alor Gajah and Jasin respectively has increased by 7316.1 hectares and 4750.25 hectares from 1999 to 2019. Moreover, in 2019, every 1 hectare of UiTM Alor Gajah and Jasin respectively contributes to 51.11 hectares and 43.27 hectares of developed land in ten kilometres radius. The increment of the land conversion into the developed area within the offset is the most significant evidence in which it shows that the presence of UiTM Melaka has played a vital role to increase the number of local industries. This is in line with the aspirations of UiTM to be a driver of economic development of the country. Thus, it has produced countless opportunities and succour to its local industries and communities.

At one point, lack of direct interaction and academic engagement between universities and local industry has influenced the exchange of information on the development of industrial progress. Nevertheless, universities' continuous efforts in collaboration with industry, government, communities, and other universities are crucial. This is because there are some noteworthy benefits of collaborating with universities such as talent development, research and innovation, global networking, and community outreach. Hence, university-industry linkages are important as industry players are also benefited through this collaboration (Filippetti \& Savona, 2017; Hoc \& Trong, 2019; Outamha \& Belhcen, 2020).

Due to the above argument, this study intends to identify economic impacts of UiTM Melaka on local industry development. Furthermore, the government has spent multi-million investment in developing these campuses in order to ensure that the local industry continuously gets benefits from the establishment of a university in its area and this effort is continued to realize the country's vision. These substantial contributions signify the success of the university and Melaka state government in boosting economic growth. The findings are useful in providing some insights for university management and policymakers to re-design and develop accurate approaches and policies to consolidate the university-industry linkages management in local industry development in the future. 


\section{Literature Review}

Local industry or business can be defined as a company which provides goods or services to a local population. Though most often used when referring to a locally owned business, the term may also be used to describe a franchise or corporate branch operating within a local area. In other words, a company which provides goods or services to a local population is considered as a local business. This business type is often referred to by the phrase brick and mortar. This means that it refers to a traditional street-side business that offers products and services to its customers, face-to-face in an office or store that the business owns or rents. For example, local grocery stores and banks are often described as brick and mortar businesses.

On the other hand, the establishment of a higher learning institution at a certain place normally involves careful considerations by the parties involved such as the policy makers, and the local authorities. Careful considerations should be made since the existence of a higher learning institution at a certain place can contribute significant influences on the social and economic of the existing community and industry in the immediate vicinity, especially the local industry or business. In fact, often, a higher learning institution is set up for the purpose of developing certain places, whether in terms of social or economic.

This phenomenon is best described from the perspective of growth pole theory (Figure 1) which was first introduced by Francois Peroux in 1949. According to Gavrilă-Paven and Bele (2017), a growth pole can be described as "1. a point of economic growth; 2 . a central location of economic activity; 3 . a point where economic growth starts and spreads to surrounding areas; 4. an urban location where economic activity ignites growth and better quality of life in the urban periphery" (p. 209). Based on the definitions given, it can be seen that there is a strong relationship between a growth pole and economic development and urbanization. The most important idea that is needed to be understood is that economic development and urbanization take place around a specific place, not spread over an entire region, for example. In the context of this research, a higher learning institution acts as a growth pole which has attracted local industry development surrounding it.

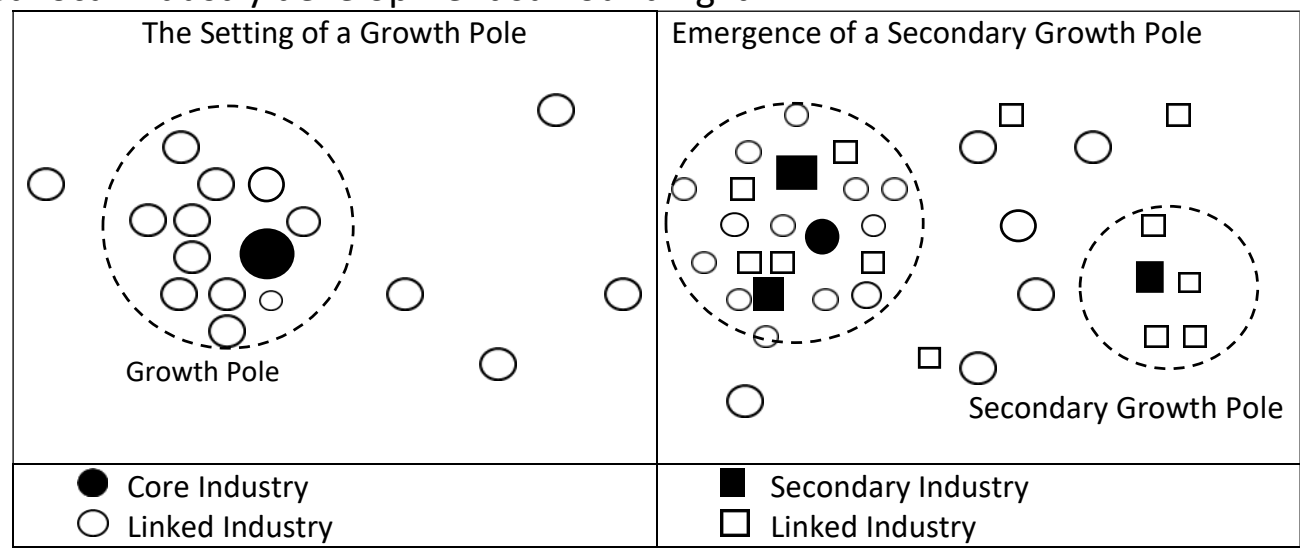

Figure 1. Growth Pole Theory

This is further demonstrated when a higher learning institution is considered to be an asset to the local industries where it spends money on the local industries and employs local workers. This is known as market opportunity for the local industry. Di Nauta et al. (2018) explained that a higher learning institution is indeed responsible for the development of its local vicinity where it settled in. In the case of Universiti Teknologi MARA (UiTM) Alor Gajah, Melaka which was established in 1996, undeniably, it has become one of the factors that 
influences the development at Lendu area in Alor Gajah. Within the 20 years period, the land conversion into the developed area is also noticed as quite significant. The conversions of the land into developed areas can be seen along the Alor Gajah district where UiTM Alor Gajah is located. The land-use conversions are mainly due to human settlements and business areas. This is true especially when higher learning institutions affect growth through a more mechanical "demand" channel. This happens when there is increased consumption from students, staff, and the universities' buying of local goods and services (Valero and Van Reenen, 2019).

Furthermore, it is crucial to note that higher learning institution engagement with the local industries should be one of the main objectives in the establishment of any higher learning institution. A higher learning institution engagement with local industries could take many forms. Consultation and training are among them. This means that the higher learning institution is involved directly with local firms, providing assistance and research support (Trippl et al., 2015). Moreover, according to Duch et al. (2010), "The presence of a university affects the local labour market and contributes to the stock of tacit knowledge to provide formal and informal technical support". Therefore, it is not surprising that a higher learning institution can bring some significant impacts to the local industry development. Bonander et al. (2016) on the other hand believes that knowledge transfer, for example, can encourage commercial start-ups to locate in the vicinity of higher learning research centres.

Another impact that could be left by a higher learning institution to its local industry is in terms of source of manpower or human resource. The establishment of a higher learning institution at a certain place will draw the community to settle around the place or the place nearby and thus they can become the source of manpower. One of the reasons for this is the job opportunities which are increasing every year as a result of the establishment of the higher learning institution has attracted a number of people to move to the place (Yazid Saleh et al., 2012). This has contributed to the economic development of the place where more sources of manpower are accessible and thus expanding the local industry. Ehinmowo \& Eludoyin (2010) also found in their research that a number of people moved to the area nearby Adekunle Ajasin University since there are more job opportunities and this has made the local industry flourish.

The discussion shows that higher learning institutions play a crucial role in the development of local industry or business. Section Results and Discussion of the paper highlights the aspects in which UiTM Melaka as one of the higher learning institutions in Malaysia has contributed to Melaka's local industry or business development.

\section{Methodology}

The research design of this study is descriptive design which aimed to describe the research problem accurately using quantitative data. It comprises descriptive statistics which explained the demographic profile of respondents and frequency analysis was also made.

A set of questionnaires is devised to analyse the significant impacts to local industry development contributed by UiTM Melaka towards three targeted populations near the campuses, Alor Gajah, Bandaraya Melaka, and Jasin.

This study was carried out using a simple random sampling technique with structured questionnaires where a face to face approach was employed to provide short briefing about this study to respondents as well as data collection. There were 50 respondents from the local industries which were located around $10 \mathrm{~km}$ radius nearby the three campuses participated by answering given questionnaires. 
The research objectives of this study are:

1. The economic impacts of the establishment of UiTM to the development of local industries.

2. The important contributions of UiTM on the development of local industries. The research questions for this study are:

1. What are the economic impacts of the establishment of UiTM to the development of local industries?

2. What are the important contributions of UiTM on the development of local industries?

The questionnaire used for this study was divided into two sections. Section A aimed to gain a demographic profile of respondents and Section B focused on the economic impacts for instance types of industry, business growth, annual gross income expansion, market opportunities, manpower, and training towards the local industries nearby. The questionnaire consists of various types of questions for example open ended question yes/no answers, closed ended questions, and ranked questions.

\section{Results and Discussion}

Table 2. Demographic Profile

\begin{tabular}{|c|c|c|}
\hline & Frequency & Per cent \\
\hline \multicolumn{3}{|l|}{ Location (by District) } \\
\hline Alor Gajah & 21 & $42 \%$ \\
\hline Melaka Tengah & 20 & $40 \%$ \\
\hline Jasin & 9 & $18 \%$ \\
\hline Total & 50 & $100 \%$ \\
\hline \multicolumn{3}{|l|}{ Types of Company } \\
\hline Locally Owned & 50 & $100 \%$ \\
\hline \multicolumn{3}{|l|}{ Types of Ownership } \\
\hline Bumiputera & 41 & $82 \%$ \\
\hline Non-Bumiputera & 9 & $18 \%$ \\
\hline Total & 50 & $100 \%$ \\
\hline \multicolumn{3}{|l|}{ Category of Industry } \\
\hline Small Industry & 41 & $82 \%$ \\
\hline Medium Industry & 8 & $16 \%$ \\
\hline Heavy Industry & 1 & $2 \%$ \\
\hline Total & 50 & $100 \%$ \\
\hline
\end{tabular}

Table 2 showed the demographic profile of the participants. As for the location of the companies, $42 \%$ of the participants made their business at Alor Gajah district, $40 \%$ at the town area (Melaka Tengah) and $18 \%$ at Jasin district. All the business is $100 \%$ locally owned. The type of companies owned by the participants is $100 \%$ locally owned with $82 \%$ owned by Bumiputera and $18 \%$ by the non-Bumiputera. Next, $82 \%$ of the participants' business is categorised as a small industry, $16 \%$ of them is under medium industry, and only $2 \%$ is categorised as heavy industry. Alor Gajah and Jasin district in the state of Melaka which were 
chosen as the area of interest for this study are rural areas. The areas are surrounded by several rural communities accompanied by facilities such as schools, places of worship, and community centres. Thus, this is the reason most of the businesses exist nearby are categorised as small industry and locally owned.

Research Question 1: What are the economic impacts of the establishment of UiTM to the development of local industries?

Table 3. Types of Local Businesses nearby UiTM Melaka Branch campuses

\begin{tabular}{|c|c|c|}
\hline Items & Frequency & Per cent \\
\hline \multicolumn{3}{|l|}{ Services } \\
\hline Food \& Beverages & 26 & $52 \%$ \\
\hline Printing \& Stationery & 8 & $16 \%$ \\
\hline Health \& beauty & 5 & $10 \%$ \\
\hline Electronics & 2 & $4 \%$ \\
\hline Transportation \& accommodation & 2 & $4 \%$ \\
\hline Education & 1 & $2 \%$ \\
\hline Others & 3 & $6 \%$ \\
\hline Sub-total & 47 & $94 \%$ \\
\hline \multicolumn{3}{|l|}{ Manufacturing } \\
\hline Food \& beverages & 1 & $2 \%$ \\
\hline Footwear & 1 & $2 \%$ \\
\hline Sub-total & 2 & $4 \%$ \\
\hline \multicolumn{3}{|l|}{ Construction } \\
\hline Sub-construction & 1 & $2 \%$ \\
\hline Sub-total & 1 & $2 \%$ \\
\hline Total & 50 & $100 \%$ \\
\hline
\end{tabular}

Table 3 displayed the types of local businesses nearby all UiTM Melaka Branch campuses. The businesses are divided into three main categories. Firstly, the service category which has the highest number of business varieties. Food and beverages service took $52 \%$, and printing and stationery service is the second, which is $16 \%$. Second, as for the manufacturing category, $2 \%$ is the food and beverages business, and another $2 \%$ is footwear. Third, the sub-construction is $2 \%$ of all the participants' businesses. This percentage shows that small industries, especially in food and beverages businesses, are the most thriving businesses as they are demanding businesses and highly sought after by the surrounding community and UiTM community. It must be noted that the food and beverage business does not only cater for everyday consumption but sometimes for the university's events as well. Printing and stationery business is second after food and beverages business as this is also considered as essential necessity for students. This result is concurrent with Yazid Saleh et al. (2012)'s study on the socio-economic impacts on a local polytechnic college where the establishment of the college could boost the nearby business in the area especially in food and cleaning services, respectively. 
Table 4. Company's Annual Gross Income Gained from the UiTM's establishment

\begin{tabular}{|c|c|c|}
\hline & Frequency & Per cent \\
\hline $0 \%-25 \%$ & 14 & $28 \%$ \\
\hline $26 \%-50 \%$ & 14 & $28 \%$ \\
\hline $51 \%-75 \%$ & 11 & $22 \%$ \\
\hline $76 \%-100 \%$ & 11 & $22 \%$ \\
\hline Total & 50 & $100 \%$ \\
\hline
\end{tabular}

Table 4 showed that the estimated percentage of their company's gross income gained from the establishment of the nearby UiTM campus. $56 \%$ of the participants revealed that their profit income percentage gained is almost to $50 \%$ of their estimated annual gross income. Other participants disclosed their gained income from UiTM's establishment is more than $50 \%$ with $22 \%$ between $51 \%-75 \%$ of their annual gross income, and the remaining $22 \%$ is $76 \%$ to $100 \%$. These findings are aligned with Di Nauta et al. (2018) study in which the existence of a tertiary institution in an area managed to improve the local vicinity surrounding it.

\section{Research Question 2: What are the important contributions of UiTM on the development of local industries?}

Table 5. The importance of these aspects of UiTM's contributions to the local community.

\begin{tabular}{|c|c|c|c|c|c|}
\hline Domains & $\begin{array}{c}\text { Most } \\
\text { important }\end{array}$ & Important & $\begin{array}{c}\text { Slightly } \\
\text { important }\end{array}$ & $\begin{array}{c}\text { Least } \\
\text { important }\end{array}$ & Total \\
\hline $\begin{array}{c}\text { Market } \\
\text { opportunity }\end{array}$ & $\begin{array}{c}30 \\
(60 \%)\end{array}$ & $\begin{array}{c}8 \\
(16 \%) \\
\end{array}$ & $\begin{array}{c}3 \\
(6 \%) \\
\end{array}$ & $\begin{array}{c}9 \\
(18 \%) \\
\end{array}$ & $\begin{array}{c}50 \\
(100 \%) \\
\end{array}$ \\
\hline Consultation & $\begin{array}{c}5 \\
(10 \%)\end{array}$ & $\begin{array}{c}26 \\
(52 \%)\end{array}$ & $\begin{array}{c}11 \\
(22 \%)\end{array}$ & $\begin{array}{c}8 \\
(16 \%)\end{array}$ & $\begin{array}{c}50 \\
(100 \%)\end{array}$ \\
\hline $\begin{array}{l}\text { Human } \\
\text { resources }\end{array}$ & $\begin{array}{c}5 \\
(10 \%)\end{array}$ & $\begin{array}{c}11 \\
(22 \%)\end{array}$ & $\begin{array}{c}12 \\
(24 \%)\end{array}$ & $\begin{array}{c}22 \\
(44 \%)\end{array}$ & $\begin{array}{c}50 \\
(100 \%)\end{array}$ \\
\hline Training & $\begin{array}{c}10 \\
(20 \%)\end{array}$ & $\begin{array}{c}5 \\
(10 \%)\end{array}$ & $\begin{array}{c}24 \\
(48 \%)\end{array}$ & $\begin{array}{c}11 \\
(22 \%)\end{array}$ & $\begin{array}{c}50 \\
(100 \%)\end{array}$ \\
\hline Total & $\begin{array}{c}50 \\
(100 \%)\end{array}$ & $\begin{array}{c}50 \\
(100 \%)\end{array}$ & $\begin{array}{c}50 \\
(100 \%)\end{array}$ & $\begin{array}{c}50 \\
(100 \%)\end{array}$ & \\
\hline
\end{tabular}

The participants were asked to rate the importance of these four aspects of contribution that they felt UITM has contributed so far. $60 \%$ of them rated market opportunity as the most important, $52 \%$ rated consultation as important. Meanwhile human resources and training were rated $48 \%$ and $44 \%$ respectively. This result is in line with their open-ended responses where it stated that the majority of them established their business near UiTM campus due to its strategic location for their business. In other words, they see it as an opportunity to boost their business. This result is similar to Yazid Saleh et.al (2012)'s study which revealed that local communities agreed on the existence of any tertiary institution because it can act as a catalyst to the increase in the establishment of new business surrounding the institution.

\section{Conclusion}

Based on the findings and discussions above, the establishment of UiTM provided positive growth on the economic impacts as well as offered vital contributions to local industries near 
the campuses. These facts are significant in helping the small industries to keep growing specifically in the sectors such as food and beverages, printing and stationery, transportation, and accommodation. The increase of those respective company's annual gross income which partly came from UiTM, should be a factual proof to believe that their businesses expansion will be disrupted if UiTM is being abolished. On top of that, UiTM itself should plan more initiatives in establishing the linkages with the local industries from all relevant aspects such as training, consultation, and corporate social responsibilities. There are plenty of events, project-based, and edutainment activities that can be conducted to maintain a healthy and beneficial relationship between higher learning institutions and industry. Due to that reason, this matter definitely will lead to the expansion of market opportunities, job opportunities as well as business growth. This scenario possibly provides widen positive competitive advantages as the push factor for the local industries to keep on growing especially focusing on market opportunity, human resource, training, and consultation aspects. Therefore, an in- depth study towards the respective four aspects of UiTM Melaka's contributions on economic impacts should be undertaken for future research.

The findings of the study are in line with the evidence found in the literature where increases in university presence are positively associated with faster subsequent economic growth. Understanding the mechanisms through which the university effect works is an important area to investigate further. The role for innovation and human capital supply although small, show that the university effects do not appear to bedriven by demand or transfers into a region. Better data on the flow of business-university linkages, movements of personnel and other collaborations would help in solving the basic mechanisms. In addition, focusing on the relationships between universities and local economic performance in individual countries where better causal designs and richer university data is available would be a useful expansion.

\section{Acknowledgement}

We would like to thank Universiti Teknologi MARA (UiTM) for granting Bestari Research Grant (600-RMC/DANA 5/3/BESTARI (TD) (003/2019)) on Kajian Impak 20 Tahun UiTM and The Landsat data was available from the U.S. Geological Survey (USGS).

\section{References}

Bonander, C., Jakobsson, N., Podestà, F., \& Svensson, M. (2016). Universities as engines for regional growth? Using the synthetic control method to analyze the effects of research universities. Regional Science and Urban Economics, 60, 198-207.

Di Nauta, P., Merola, B., Caputo, F., \& Evangelista, F. (2018). Reflections on the role of university to face the challenges of knowledge society for the local economic development. Journal of the Knowledge Economy, 9, 180-198.

Duch, N., García-Estévez, J., \& Parellada, M. (2010). Do universities affect firms' location decisions? Evidence from Spain. Spain: Barcelona Institute of Economics.

Ehinmowo, A. A., \& Eludoyin, O. M. (2010). The university as a nucleus for growth pole: Example from Akungba - Akoko, Southwest, Nigeria. International Journal of Sociology and Anthropology, 2(7), 149-154.

Filippetti, A., \& Savona, M. (2017). University-industry linkages and academic engagements: individual behaviours and firms' barriers. Introduction to the special section. Journal of Technology Transfer, 42, 719-729. 
Gavrilă-Paven, I., \& Bele, I. (2017). Developing a growth pole: Theory and reality. In Daróczi, M., Robak, E., \& Vinogradov, S. (Eds.), Management, organizations and society (pp. 209-215). Budapest: Agroinform Publishing House.

Hoc, L. H., \& Trong, N. D. (2019). University-industry linkages in promoting technology transfer: A study of vietnamese technical and engineering universities. Science, Technology and Society, 24(1), 73-100.

Outamha, R., \& Belhcen, L. (2020). What do we know about university-industry linkages in Africa? In Abu-Tair A., Lahrech A., Al Marri K., Abu-Hijleh B. (Eds.), Proceedings of the II International Triple Helix Summit, Lecture (pp. 375-391). Switzerland: Springer.

Trippl, M., Sinozic, T., \& Lawton Smith, H. (2015). The role of universities in regional development: Conceptual models and policy institutions in the UK, Sweden and Austria. European Planning Studies, 23(9), 1722-1740.

Valero, A., \& Van Reenen, J. (2019). The economic impact of universities: Evidence from across the globe. Economics of Education Review, 68, 53-67. 